\title{
Dust-related impacts of mining operations on rangeland vegetation and soil: a case study in Yazd province, Iran
}

Shahab IbrahimPour

Ardakan University

Alireza KhavaninZadeh ( $\sim$ a.r.khavaninzadeh@gmail.com )

Ardakan University

Ruhollah Taghizadeh mehrjardi

Ardakan University

Hans De Boeck

Universiteit Antwerpen

Alvina Gul

NUST: National University of Sciences and Technology

\section{Research Article}

Keywords: Ecological indicators, Seed quality, Land degradation, Range lands, Mining operations, Soil microbial respiration.

Posted Date: June 2nd, 2021

DOl: https://doi.org/10.21203/rs.3.rs-245412/v1

License: (c) (i) This work is licensed under a Creative Commons Attribution 4.0 International License.

Read Full License

Version of Record: A version of this preprint was published at Environmental Earth Sciences on July 8th, 2021. See the published version at https://doi.org/10.1007/s12665-021-09758-5. 


\section{Abstract}

Destructive mining operations are affecting large areas of natural ecosystems, especially in arid lands. The present study aims at investigating the impact of iron mine exploitation on vegetation and soil in Nodoushan (Yazd province, central Iran). Based on the dominant wind, topography, slope, vegetation and soil of the area, soil and vegetation parameters close to the mine were recorded and analyzed according to the distance from the mine. In order to obtain the vegetation cover, a transect and plot on the windward and leeward side of the mine, with $100 \mathrm{~m}$ intervals and three replicates at each sampling location was used, yielding 96 soil samples. The amount of dust on the vegetation, the seed weight and seed germination rate of Artemisia sp. as the dominant species within the area, and the soil microbial respiration were measured. The relationship between vegetation cover and distance from the mine was not linear, which was due to an interplay between pollution from the mine and local grazing, while other factors did increase or decrease linearly. The results showed that, as the distance from the mine increased, the weight of 1000 seeds of Artemisia sp. was significantly increased from 271 to $494 \mathrm{mg}$ and seed germination rate and soil microbial respiration were significantly increased from 11.7 to $48.4 \%$ and from 4.5 to $5.9 \mathrm{mg} \mathrm{CO}_{2} \mathrm{~g}^{-1}$ soil day ${ }^{-1}$ respectively, while the amount of dust significantly decreased from 43.5 to $6 \mathrm{mg}$ (g plant) ${ }^{-1}$ between the distance of 100 to $600 \mathrm{~m}$ from the mine in the leeward direction. A similar trend was observed in the windward side, though negative effects were lower compared to the same distance along the leeward sample locations. The direct and indirect effects on plant growth and health from mining impacts generally decreased linearly with increasing distance from the mine, up to at least $600 \mathrm{~m}$. Our study serves as a showcase for the potential of bio-indicators as a cost-effective method for assessing impacts of mining activities on the surrounding environment.

\section{Introduction}

Mining operations increasingly impact natural ecosystems, especially in arid lands (Dudca and Adriana 1997). The effects of exploitative activities vary in different areas and local communities (Duhaime 2004), but the most common destructive effects include changes in the landscape, water acidification, soil contamination, destruction of vegetation, and health risks for local communities (Liu et al. 2014). Degradation caused by surface mining largely depends on the topographic conditions, the intensity and prevalent direction of the wind, and soil properties before mining (Grantz et al. 2003; Bujalský et al., 2014). The degradation of vegetation and soil in natural habitats results in adverse consequences such as decreasing vegetation cover and vigor, and reduced biological soil activity that may either be irreversible or require a long period to revert to the previous state, especially in arid regions (Darley 1996; Turner 2013). The combined effects often result in adverse impacts on local communities, especially in rural areas. Thus, studying the effects of mining and determining the extent and severity of vegetation and soil degradation is needed for future sustainable development by improved land management and revegetation in these valuable natural areas. There have been several studies on the effect of mining on vegetation and natural ecosystems in arid and semiarid regions (Sharifi et al. 1997; Bech et al. 2012) which mainly focused on heavy metals. Hamidian et al. (2014) reported that the mean concentrations of 
heavy metals were significantly higher in soils close to a copper mine in Darrehzereshk, Taft, Yazd province, Iran, with a significant difference between the concentration of metals in all categorized regions based on the distance from the mine. Bech et al. (2012) determined that significantly higher concentrations of heavy metals in soil and vegetation of the area surrounding lead mine tailings, indicating negative impact of the mine on soil and vegetation in the western Mediterranean. Santos et al. (2012) found high concentration of heavy metals in native plant species grown in the tailings dump sites of lead, copper and zinc mines in the Querétaro region of Mexico, with accumulation of metals being species specific. Kumar (2015) reported vegetation changes depending on the type of mine, vegetation and levels of dust. The impact on vegetation has led to recommendations to protect plants against being exploited by wild animals (e.g. Booth et al. 2003 in a study on Artemisis spp). Furthermore, Hector et al. (2009) concluded that there is the risk of heavy metal contamination and their transmission to animals, and as a result, the whole biological cycle, due to the accumulation of heavy metals in vegetation. This particular study determined the leeward impact of mining operations by using several biological indicators. Determining this outward impact is needed to enable natural resource managers to evaluate and calculate financial damages resulting from land degradation around the mine. For this, we focus on factors that have been scarcely considered by researchers in relation to the impact of mining on habitats and natural ecosystems.

Considering reported negative impacts of mining operations in rangeland ecosystems and the increasing number of mines recently within the area, there is a need for appropriate and cost-effective indicators that enable to assess and monitor mining impacts. Hence, our study aims to estimate the mining impacts on a number of environmental variables and how impacts relate to the distance from the mine. This could then be used as an indicator of potential damage elsewhere, and as a guide for improving and reconstructing regions around mining areas. Specifically, we focused on biological indicators as a potentially cost-effective method to assess and monitor mining impacts on soil and vegetation in an area that has seen an increasing number of mines during last years. This evaluation of bio-indicators was performed near the Suork iron ore mine in Iran, Yazd province, as a case study. We selected this site because many similar mines exist in the province and the mine's surroundings are considered ecologically valuable rangelands.

\section{Materials And Methods}

\subsection{Study area and general sampling strategy}

The study area is located in the center of Iran, Yazd province $\left(31^{\circ} 58^{\prime} \mathrm{N}, 53^{\circ} 30^{\prime} \mathrm{E}\right), 2100 \mathrm{~m}$ a.s.l. (above sea level) with a slope of $17 \%$. The main period of the precipitation is January to April $(74 \mathrm{~mm})$, with nearly $18 \%$ falling as snow and the rest as rain. The average annual temperature and precipitation is equal to $14^{\circ} \mathrm{C}$ and $93 \mathrm{~mm}$, respectively. The flora in the region comprises 19 annual and perennial species, with Artemisia sieberi L. as a dominant species (Abdollahi et al., 2015). The prevailing wind speed and the number of dust days is equal to $14.8 \mathrm{~m} / \mathrm{s}$ and 50 days per year in the region, respectively. The soils of the region are shallow to deep and classified as Calcisols (Taghizadeh et al. 2020, Baxter 2007). Iron mining 
activities started in 2008 and are still actively ongoing. The mine has two circuits of grinding and aggregating and dry magnetic separation with an annual supply of 430000 tons of mineral (mainly magnetite) of $50 \%$ grade and produces about 300 thousand tons of iron ore concentrates of $66 \%$ grade. Volume of mining tailings is equal to around 3 million tons annually, which are deposited around the mine at distance of less than 1 kilometer from the mine. The village of Surk is located $4 \mathrm{~km}$ from the mine in leeward direction, and has a population of 225.

The area studied was categorized in terms of distance to the iron ore mine along the prevailing wind direction, and topography. Systematic sampling was performed in $100 \mathrm{~m}$ intervals from the mine. Landsat satellite imagery was used as an auxiliary tool in order to detect similar land units on the rangelands, and the location of the sampling points was determined according to tone changes of images and the slope of the area, as homogeneous land units have similar tone (Zonneveld I.S 1989). The measured variables include the percentage of vegetation cover, the weight of 1000 seeds, the germination rate of the dominant seed species, soil microbial respiration rate and percentage of dust in the region. To measure the soil and vegetation factors in the habitat near the mine in this research, first, samples were grouped based on the distance from the mine, in $100 \mathrm{~m}$ groups (Fig. 2). Because the terrain (especially steep slopes) made it difficult to find accessible and homogeneous sampling conditions far from the mine, no plots were laid out farther than $600 \mathrm{~m}$ from the mine. Location of sampling groups, transects and plots located along the transects has been illustrated in Fig. 2 based on the distance from the mine and wind direction.

\subsection{Aboveground sampling and measurements Vegetation cover}

Sampling was carried out in the main growing season, starting November 2016 and ending late January 2017 with the completion of the plant life cycle i.e. seed formation. Sampling around the mine was done in topographic units with homogeneous slope, direction and topography. In order to obtain the vegetation cover (\%), $35 \mathrm{~m}$ transects with 3 plots of size 1 by $2 \mathrm{~m}$ (Moghadam 2009) perpendicular to the main transect (Fig. 2) were used, giving a total of i.e. 18 and 6 transects and plots in leeward and windward directions, respectively (Fig. 2). The size of the plots was determined based on the distribution pattern of the species (minimum area method) and the number of plots needed was based on mean and variance data obtained by initial vegetation cover sampling in the study area (Moghadam 2008).

\section{Seed weight}

To measure the weight of 1000 Artemisia sp. seeds,250 seeds were sampled from plots at each sampling point (100-meter interval) in 5 replicates. Hence, 30 and 10 samples were used for seed measurement in leeward and windward directions, respectively. The weight of 250 seeds was measured using a balance with $0.0001 \mathrm{~g}$ sensitivity and average of five replicates (each consisting of 250 seeds) was multiplied by 4 to obtain the 1000 seed weight.

\section{Dust deposited on the plant}


To determine the weight of the deposited soil particles and dust on plants, the aerial plant parts were inserted into a bag and shaken, then dust, seeds and small plant parts that remained in the bag were passed through meshes of size $14(1180 \mu \mathrm{m}), 18(1000 \mu \mathrm{m})$ and $25(710 \mu \mathrm{m})$ to remove particles with more than $710 \mu m$ diameter from the aerial parts of the plants (Lohr V I, Pearson-Mims C H, 1996). Three plant samples in each plot were taken, for a total of 54 and 18 plant samples in leeward and windward direction, respectively, to determine dust deposition. We sampled plants of similar size in each of the plots. The weight of the dust was measured using a balance with $0.0001 \mathrm{~g}$ sensitivity. In the final stage, dust deposited was reported relative to the weight of the sampled plant parts by dividing weight of deposits by plant weight, reported as $\mathrm{g}$ dust/ $\mathrm{g}$ plant biomass.

\section{Seed germination rate}

The seeds of dominates species within the study area, i.e. Artemisia seiberi L., were disinfected using sodium hypochlorite and then placed per batch of 10 in a sterile container with a wetted filter paper using distilled water. To measure seed germination, five containers were used on each sampling point, for a total of 30 and 10 containers in leeward and windward directions, respectively. The containers were placed in an incubator for 10 days at $25^{\circ} \mathrm{C}$. The number of seeds which had germinated were counted daily.

\subsection{Soil sampling and measurements}

Soil samples were collected at a depth of $0-10 \mathrm{~cm}$ in 96 points located within the plots, using a trowel, and the soil was placed in a plastic bag and coded. In each plot, 4 soil samples were taken and analyzed, for a total of 72 and 24 samples in leeward and windward directions, respectively. The samples were subsequently placed inside a cooling container containing ice, and transferred to the laboratory to measure the soil microbial respiration rate.

\section{Soil microbial respiration}

Surface soils were first placed into a closed container and were ground to pass a 2-mm sieve and then a same volume of distilled water was added to each container to reach $50 \%$ field capacity. Then, $20 \mathrm{~mL}$ of $0.05 \mathrm{~N} \mathrm{NaOH}$ was poured into smaller containers and placed in container with soil. The container caps were sealed using wax tape and incubated at $28^{\circ} \mathrm{C}$ for 24 hours. In the final stage, the extra $\mathrm{NaOH}$ was titrated using $\mathrm{HCl}$ and soil microbial respiration was measured by titration method (ISO 16072, 2002). The following formula was used to convert the excess of titrated $\mathrm{NaOH}$ to $\mathrm{CO}_{2}$ released by microbial respiration:

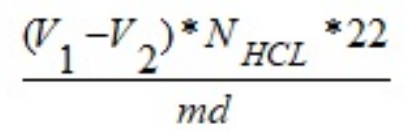

$\mathrm{V}_{1}$ and $\mathrm{V}_{2}$ is the volume $(\mathrm{ml})$ of $\mathrm{HCl}$ consumed in the control and in the test sample respectively, $\mathrm{N}_{\mathrm{HCl}}$ : Normality of $\mathrm{HCl} ; \mathrm{m}$ is the mass of the moist soil sample, in grams; $d$ is the dry mass fraction of the moist soil. 


\subsection{Statistical analysis}

The effect of the distance from the mine was determined by analysis of variance as a parametric method, and differences between the measured variables were evaluated using post-hoc analysis and Duncan's Multiple range test. Before analyzing, normality distribution of data and homogeneity of variance were evaluated by Kolmogorov-Smirnov and Levene's tests, respectively. Transformation methods such as the Box-Cox method (Box and Cox 1964) were used where model assumptions were not met. Relationships between dependent and independent variables were evaluated using regression and Pearson correlation. SPSS software version 22 was used for data analysis.

\section{Results}

\subsection{Vegetation cover (\%)}

The maximum vegetation cover (18.4\%) was observed at a distance of 200 meter from the mine in windward side while minimum was observed at $100 \mathrm{~m}(11.5 \%)$ in leeward direction. Going away from the mine in leeward direction, vegetation cover first increased until 300-400 m, after which the cover decreased again (Table 1).

Table 1

Percentage of vegetation cover at different distances from the iron ore mine

\begin{tabular}{|c|c|c|c|c|c|c|c|c|}
\hline \multirow[t]{3}{*}{ Vegetation } & \multicolumn{8}{|c|}{ Distance from the mine } \\
\hline & \multirow[b]{2}{*}{$\begin{array}{l}(100 \\
\mathrm{m})\end{array}$} & \multirow[b]{2}{*}{$\begin{array}{l}(200 \\
\mathrm{m})\end{array}$} & \multirow[b]{2}{*}{$(300 \mathrm{~m})$} & \multicolumn{2}{|c|}{ Leeward } & \multicolumn{2}{|c|}{ Windward } & \multirow[b]{2}{*}{$(200 \mathrm{~m})$} \\
\hline & & & & $\begin{array}{l}(400 \\
\mathrm{m})\end{array}$ & $\begin{array}{l}(500 \\
\mathrm{m})\end{array}$ & $(600 \mathrm{~m})$ & $(100 \mathrm{~m})$ & \\
\hline Mean & a 11.5 & b 13.2 & c 16.5 & $12.8^{b}$ & b 13.1 & ${ }^{c} 2.17$ & b 14.1 & d 18.4 \\
\hline Max & 12.2 & 13.5 & 17.0 & 16.5 & 13.4 & 11.8 & 14.5 & 19. \\
\hline Min & 11.3 & 12.9 & 16.0 & 15.8 & 12.9 & 11.2 & 13.5 & 18.0 \\
\hline Std & 0.5 & 0.3 & 0.5 & 0.4 & 0.2 & 0.3 & 0.5 & 0.5 \\
\hline C.V & 4.3 & 2.3 & 3.0 & 3.1 & 1.5 & 1.7 & 3.6 & 2.7 \\
\hline
\end{tabular}

Trend of vegetation cover (\%) was nonlinear based on the distance from the mine, with distance explaining $63 \%$ of the variance in cover (Fig. 3 ).

\subsection{Weight of 1000 seeds}


Results showed there is a significant difference $(P<0.01)$ in 1000 seeds weight of the dominated species (Artemisia seiberi $\mathrm{L}$ ) among distance groups, indicating that seed quality depended on the distance from the mine (Table 2).

Table 2

Seed weight $(\mathrm{mg})$ of the dominant species in the study area i.e. Artemisia seiberi L. at different distances from the mine

\begin{tabular}{|c|c|c|c|c|c|c|c|c|}
\hline \multirow{3}{*}{$\begin{array}{l}\text { Seed } \\
\text { weight }\end{array}$} & \multicolumn{8}{|c|}{ Distance from the mine } \\
\hline & \multicolumn{4}{|c|}{ Leeward } & \multicolumn{4}{|c|}{ Windward } \\
\hline & $\begin{array}{l}(100 \\
\mathrm{m})\end{array}$ & $\begin{array}{l}(200 \\
\mathrm{m})\end{array}$ & $\begin{array}{l}(300 \\
\mathrm{m})\end{array}$ & $\begin{array}{l}(400 \\
\mathrm{m})\end{array}$ & $(500 \mathrm{~m})$ & $\begin{array}{l}(600 \\
\mathrm{m})\end{array}$ & $(100 \mathrm{~m})$ & $(200 \mathrm{~m})$ \\
\hline Mean & a 271 & b 336 & b 353 & c 404 & $\mathrm{~d} 428$ & e 494 & b 374 & ${ }^{c} 423$ \\
\hline Max & 330 & 380 & 400 & 430 & 450 & 530 & 430 & 450 \\
\hline Min & 210 & 300 & 300 & 370 & 410 & 460 & 260 & 400 \\
\hline Std & 33 & 25 & 30 & 17 & 13 & 10 & 66 & 15.8 \\
\hline$\%$ C.V & 12.2 & 7.4 & 8.5 & 4.2 & 3.04 & 2.02 & 17.6 & 3.70 \\
\hline
\end{tabular}

Results show that the 1000 seed weight increases linearly when moving away from the mine. Minimum 1000 seeds weight was $271 \mathrm{mg}$ at the nearest distance $(100 \mathrm{~m})$ whereas the maximum weight was 494 $\mathrm{mg}$ at a distance of $600 \mathrm{~m}$ from the mine (Table 2). The trend of variation in weight of 1000 seeds in relation to the distance from the mine was linear and increased with increasing distance. More than $84 \%$ of the seed weight variance was explained by distance from the mine, indicating clear impact of mining operations on seed weight of the dominant species within the study area (Fig. 4).

\subsection{Dust deposited on the plant}

The highest deposited dust was $43.5 \mathrm{mg} / \mathrm{g}$ plant at a distance of $100 \mathrm{~m}$ from the mine, while the minimum was recorded at the maximum distance $(600 \mathrm{~m})$ and equal to $6.0 \mathrm{mg} / \mathrm{g}$ plant, i.e. decreasing more than 7 times compared to the location nearest to the mine (100 meters). Comparing the dust deposited on plants by Duncan's test indicated a significant $(P<0.01)$ difference between most of the pair groups (Table 3). The trend in decreasing dust deposition in relation to increasing distance from the mine was linear and explained more than $83 \%$ of the variance (Fig. 5). 
Table 3

Dust weight (mg (gr plant) ${ }^{-1}$ ) of the dominant species in the study area i.e. Artemisia seiberi L.at different distances from the mine

\begin{tabular}{|c|c|c|c|c|c|c|c|c|}
\hline \multirow{3}{*}{$\begin{array}{l}\text { Dust } \\
\text { weight }\end{array}$} & \multicolumn{8}{|c|}{ Distance from the mine } \\
\hline & \multicolumn{4}{|c|}{ Leeward } & \multicolumn{4}{|c|}{ Windward } \\
\hline & $\begin{array}{l}(100 \\
\mathrm{m})\end{array}$ & $\begin{array}{l}(200 \\
\mathrm{m})\end{array}$ & $\begin{array}{l}(300 \\
\mathrm{m})\end{array}$ & $\begin{array}{l}(400 \\
\mathrm{m})\end{array}$ & $\begin{array}{l}(500 \\
\mathrm{m})\end{array}$ & $\begin{array}{l}(600 \\
\mathrm{m})\end{array}$ & $(100 \mathrm{~m})$ & $(200 \mathrm{~m})$ \\
\hline Mean & a 43.5 & b 31.6 & b 26.4 & c 18.0 & c 14.0 & $\mathrm{~d} 6.0$ & d 9.0 & e 3.0 \\
\hline Max & 48.0 & 44.0 & 33.0 & 26.0 & 16.0 & 9.0 & 14.0 & 5.0 \\
\hline Min & 40.0 & 18.0 & 21.0 & 9.0 & 12.0 & 2.0 & 6.0 & 2.0 \\
\hline Std & 2.30 & 7.90 & 3.90 & 4.40 & 1.70 & 2.10 & 3.10 & 1.0 \\
\hline C.V & 5.2 & 25 & 15 & 24.4 & 12.1 & 35.0 & 34.4 & 33.3 \\
\hline
\end{tabular}

\subsection{Seed germination rate}

The highest rate of seed germination for Artemisia sp. was $53.6 \%$ at a distance of $200 \mathrm{~m}$ from the mine in windward, while the minimum (11.7) was recorded at the minimum distance $(100 \mathrm{~m})$ in leeward side. As the distance from the mine increases, rate of seed germination is significantly $(P<0.01)$ increased.

Results show there is a significant difference $(P<0.01)$ between most of pair groups in the rate of seed germination by Duncan's test, indicating different impact of mining operations on seed quality and rate of seed germination in the surroundings of the mine (Table 4). 
Table 4

Percentage of seed germination of the dominant species in the study area i.e. Artemisia seiberi L. at different distances from the mine

\begin{tabular}{|c|c|c|c|c|c|c|c|c|}
\hline \multirow[t]{3}{*}{ GER } & \multicolumn{8}{|c|}{ Distance from the mine } \\
\hline & \multicolumn{4}{|l|}{ Leeward } & \multicolumn{4}{|c|}{ Windward } \\
\hline & $(100 \mathrm{~m})$ & $(200 \mathrm{~m})$ & $(300 \mathrm{~m})$ & $(400 \mathrm{~m})$ & $(500 \mathrm{~m})$ & $(600 \mathrm{~m})$ & $(100 \mathrm{~m})$ & $(200 \mathrm{~m})$ \\
\hline Mean & $\mathrm{a} 11.7$ & b 18.6 & ${ }^{c} 23.9$ & $\mathrm{~d} 31.9$ & e 38.9 & ${ }^{f} 48.4$ & e 36.3 & g 53.6 \\
\hline Max & 13.0 & 19.0 & 24.8 & 33.0 & 40.5 & 51.2 & 37.6 & 55.0 \\
\hline Min & 10.5 & 18.0 & 23.0 & 31.0 & 37.2 & 45.4 & 35.3 & 51.5 \\
\hline Std & 1.2 & 0.5 & 0.9 & 1.0 & 1.6 & 2.9 & 1.2 & 1.8 \\
\hline C.V & 10.3 & 2.7 & 3.8 & 3.2 & 4.1 & 5.9 & 3.3 & 3.4 \\
\hline
\end{tabular}

The trend in increasing seed germination in relation to increasing distance from the mine was linear and explained more than $82 \%$ of the variance (Fig. 6).

\subsection{Rate of soil microbial respiration}

The highest microbial respiration was $5.9 \mathrm{mg} \mathrm{CO}_{2} \mathrm{~g}^{-1}$ soil day ${ }^{-1}$ at a distance of $600 \mathrm{~m}$ from the mine while the minimum was $4.5 \mathrm{mg} \mathrm{CO}_{2} \mathrm{~g}^{-1}$ soil day ${ }^{-1}$ at the minimum distance $(100 \mathrm{~m})$, indicating more than $30 \%$ decreasing in soil microbial respiration at the distance of $100 \mathrm{~m}$ from the mine (Table 5). The results show that soil microbial respiration significantly increased by ascending from the mine, indicating significant impact of mining operation on microbial activity of the soil. 
Table 5

Soil microbial respiration ( $\mathrm{mg} \mathrm{CO}_{2} \mathrm{gr}^{-1}$ soil day-1) in different distances from the mine

\begin{tabular}{|c|c|c|c|c|c|c|c|c|}
\hline \multirow[t]{3}{*}{ TRA } & \multicolumn{8}{|c|}{ Distance from the mine } \\
\hline & \multicolumn{4}{|l|}{ Leeward } & \multicolumn{4}{|c|}{ Windward } \\
\hline & $(100 \mathrm{~m})$ & $(200 \mathrm{~m})$ & $(300 \mathrm{~m})$ & $(400 \mathrm{~m})$ & $(500 \mathrm{~m})$ & $(600 \mathrm{~m})$ & $(100 \mathrm{~m})$ & $(200 \mathrm{~m})$ \\
\hline Mean & a 4.5 & $b_{4} 4.8$ & ${ }^{c} 5.1$ & ${ }^{c} 5.2$ & $\mathrm{~d} 5.4$ & f 5.9 & ${ }^{c} 5.0$ & ${ }^{d} 5.3$ \\
\hline Max & 4.9 & 5.6 & 5.8 & 5.5 & 5.6 & 6.3 & 5.4 & 5.5 \\
\hline Min & 4.3 & 4.6 & 4.8 & 4.9 & 5.10 & 5.6 & 4.5 & 5.0 \\
\hline Std & 0.1 & 0.2 & 0.2 & 0.1 & 0.15 & 0.2 & 0.2 & 0.1 \\
\hline C.V & 3.3 & 4.4 & 5.7 & 2.9 & 2.80 & 3.5 & 4.0 & 3.0 \\
\hline
\end{tabular}

The increasing trend of soil microbial respiration with increasing distance from the mine was linear and explained more than $77 \%$ of the variance (Fig. 7).

\subsection{Relationship between variables in leeward and windward directions}

Results showed significant differences among variables when comparing them along leeward and windward sides of the mine. The amount of dust deposited on the vegetation was significantly $(P<0.01)$ higher in leeward compared to windward areas, while the opposite was found for vegetation parameters such as seed weight, vegetation cover and seed germination (Table 6). 
Table 6

Differences between variables in leeward and windward of the mine

\begin{tabular}{|c|c|c|c|c|c|c|}
\hline Parameter & $\mathbf{N}^{*}$ & Location & Mean & Std & Minimum & Maximum \\
\hline \multirow[t]{2}{*}{ Dust (mg/ gr plant) } & \multirow[t]{2}{*}{12} & L & $27^{a}$ & 10 & 2 & 48 \\
\hline & & W & $5^{b}$ & 3 & 2 & 1.4 \\
\hline \multirow[t]{2}{*}{ SW (mg) } & \multirow[t]{2}{*}{10} & L & $360^{a}$ & 70 & 210 & 450 \\
\hline & & W & $410^{b}$ & 40 & 260 & 530 \\
\hline \multirow[t]{2}{*}{$\mathrm{RES}\left(\mathrm{mg} \mathrm{CO}_{2} \mathrm{gr}^{-1}\right.$ soil day $\left.^{-1}\right)$} & \multirow[t]{2}{*}{24} & L & $5^{a}$ & 0.45 & 4.3 & 5.8 \\
\hline & & W & $5.3^{b}$ & 0.51 & 4.6 & 6.3 \\
\hline \multirow[t]{2}{*}{ GER (\%) } & \multirow[t]{2}{*}{10} & L & $32.9^{a}$ & 13.8 & 10.5 & 53 \\
\hline & & W & $46.5^{b}$ & 8.1 & 35 & 58 \\
\hline \multirow[t]{2}{*}{$\operatorname{cov}(\%)$} & \multirow[t]{2}{*}{6} & L & $14.3^{a}$ & 2.4 & 11.2 & 18 \\
\hline & & W & $17.01^{b}$ & 2.6 & 13 & 21 \\
\hline $\begin{array}{l}\text { N: Number of samples, * Comp } \\
\text { Germination COV: Cover, L: lee } \\
\text { difference }\end{array}$ & $\begin{array}{l}g \text { res } \\
\cdot W \cdot 1\end{array}$ & $\begin{array}{l}\text { ts up to } 20 \\
\text { indward, } \mathrm{Di}\end{array}$ & $\begin{array}{l}n, S W: \text { Se } \\
\text { rent letter }\end{array}$ & $\begin{array}{l}\text { weigh } \\
\text { indicat }\end{array}$ & $\begin{array}{l}\text { RES: Soil res } \\
\text { significant ( }\end{array}$ & $\begin{array}{l}\text { ration, GER: } \\
0.01)\end{array}$ \\
\hline
\end{tabular}

Results showed significant $(P<0.01)$ correlation among variables in windward and leeward side of the mine (Table 7). Correlation pattern are similar among variables for leeward and windward sides, except the correlation between vegetation cover and other variables and between seed weight and dust as well as soil respiration. 
Table 7

Correlation between variables in two directions of the mine

\begin{tabular}{|c|c|c|c|c|c|c|c|}
\hline Direction & $\mathbf{N}$ & Variables & Dust & sw & RES & GER & Cov \\
\hline & 36 & Dust & 1 & - & - & - & - \\
\hline & 30 & sW & $-0.83^{\star \star}$ & 1 & - & - & - \\
\hline \multirow[t]{5}{*}{ Leeward } & 72 & RES & $-0.90 \star \star$ & $0.91^{\star \star}$ & 1 & - & - \\
\hline & 30 & GER & $-0.90 \star \star$ & $0.86^{\star \star}$ & $0.87 \star \star$ & 1 & - \\
\hline & 18 & cov & $--0.47 \star \star$ & $0.31^{\mathrm{ns}}$ & $0.26^{\mathrm{ns}}$ & $0.34^{n s}$ & 1 \\
\hline & 12 & Dust & 1 & - & - & - & - \\
\hline & 10 & SW & $-0.30 \mathrm{~ns}$ & 1 & - & - & - \\
\hline \multirow[t]{3}{*}{ Windward } & 24 & RES & $-0.72^{\star \star}$ & $0.44^{n s}$ & 1 & - & - \\
\hline & 10 & GER & $-0.86^{\star \star}$ & $0.45^{\star}$ & $0.88^{\star \star}$ & 1 & - \\
\hline & 6 & $\mathrm{cov}$ & $-0.81^{\star \star}$ & $0.43^{\star *}$ & $0.87 * \star$ & $0.90 * *$ & 1 \\
\hline
\end{tabular}

SW: Seed weight; RES: Soil respiration; GER: Germination; COV: Cover; * $p<0.05$, ${ }^{\star \star} p<0.01$, ns: not. significant.

There was a negative and significant correlation between dust and all other variables (except seed weight) along the windward direction, suggesting negative impacts of dust on soil respiration and vegetation. We found no correlation between seed weight and soil respiration in the windward direction, indicating different impact of the mine operations on soil and vegetation depending on wind direction (Table 7). 
Table 8

Relationship between dust and vegetation parameters in leeward direction

\begin{tabular}{|c|c|c|c|c|c|c|c|}
\hline Response & Predictor & B & Std Error & $\mathrm{R} S \mathrm{q}$ & Adj R Sq & Sig (Predictor) & Sig (Model) \\
\hline \multirow[t]{3}{*}{ Germination } & Constant & -6.7 & 3.6 & \multirow[t]{3}{*}{0.83} & \multirow[t]{3}{*}{0.81} & 0.06 * & \multirow[t]{3}{*}{$\star \star$} \\
\hline & Dust & -57.2 & 22.1 & & & 0.02 * & \\
\hline & Respiration & 9.6 & 6.1 & & & $0.10 \mathrm{~ns}$ & \\
\hline \multirow[t]{3}{*}{ Seed weight } & Constant & 0.2 & 0.15 & \multirow[t]{3}{*}{0.92} & \multirow[t]{3}{*}{0.9} & 0.08 * & \multirow[t]{3}{*}{ ** } \\
\hline & Dust & -3.73 & 0.9 & & & 0.001 ** & \\
\hline & Respiration & 0.05 & 0.02 & & & 0.04 * & \\
\hline \multirow[t]{3}{*}{ Cover } & Constant & 19.1 & 0.241 & \multirow[t]{3}{*}{0.2} & \multirow[t]{3}{*}{0.15} & $0.1 \mathrm{~ns}$ & \multirow[t]{3}{*}{ ns } \\
\hline & Dust & -46.7 & -3.63 & & & $0.5 \mathrm{~ns}$ & \\
\hline & Respiration & -0.96 & 0.043 & & & $0.7 \mathrm{~ns}$ & \\
\hline
\end{tabular}

Results showed a significant relationship between seed germination and seed weight, influenced by dust and soil respiration as independent variables in the model (Table 8). Seed weight variation was mainly (>90\%) predicted by dust and soil respiration while there was no relationship between vegetation cover and dust and soil respiration indicating lower influence of vegetation cover by these factors. Seed germination and weight negatively influenced by dust while soil respiration influenced them positively.

\section{Discussion}

Changing land use is one of the most important anthropogenic interventions in natural ecosystems. The results of the study showed that mining operations in the region significantly affected the surrounding ecosystem. Most negative effects were found closest to the iron ore mine, including lower vegetation cover, seed mass, germination and soil respiration. Specifically, for vegetation cover, our results indicate a hump-shaped pattern: increasing away from the mine, but decreasing again further away. This surprising pattern is likely caused by an interplay between direct negative effects on plants by mining operations and livestock overgrazing of the rangeland. In field surveys, it was found out that ranchers do not guide livestock near the mine for grazing plants due to their awareness about potential contamination near the mine. Interviews with ranchers in the region indicated that if livestock graze close to the mine, they would be affected by various diseases, including infertility and low milk production, as well as itching due to dust penetration in sheep's wool. Disorders caused by the absorption and consumption of iron and copper elements (Humphries et al. 1983; Stadtman and Oliver 1991) can cause the above-mentioned diseases. In addition, antagonistic effects of iron and copper are reported in various studies (Suttle et al. 1985; Hansen et al. 2005). Various diseases in sheep in dry and dusty conditions have also been reported 
by Litzow (2015). Grazing vegetation with deposited dust from grinding operations and processing of iron ore around and near the mine could be the direct source of transmission of elements and poisoning of the livestock (Garick et al. 2003).

As depicted in the Fig. 3 it seems the mixed effects of grazing and mining have the key role in decreasing vegetation cover at distance of $400-500$ meters from the mine while at 600-meter, vegetation cover is increasing, indicating lower impact of mining at this distance. The major pollution caused by mine operations is air pollution by dust due to exploitation of mines. This pollution is spread by the dominant wind in the region. The results of this study revealed that plants near the mine are more affected by the dust and this pollution is significantly reduced as the distance from the mine increases. The negative impact of dust caused by mining on vegetation is reported by various researchers (e.g. Reeves and Baker 2000), who have reported the effect of type, size and amount of dust on disturbance of plant growth and reproduction.

According to our results, the seed weight of the dominant Artemisia species was significantly reduced closer to the mine. Several studies have reported the impact of mine exploitation on seed quality reduction, reproduction, plant development and growth (Hector et al. 2009) which confirm results of this study. In line we found that the greater the distance from the mine, the higher the seed germination rate of the dominant plant species, driven by decreased quality of seeds produced near the mine (i.e. lower seed weight). The negative effect of dust on the plant can be mainly explained by changing of light intensity. Increased light absorption leads to increased leaf temperatures, closure of stomata and decreased photosynthesis (Lambers et al. 2008) and changes in evapotranspiration and respiration, which can ultimately affect growth and seed production and quality (Doely 2006). Additionally, excessive absorption of iron can interfere with plant performance and healthy seed production. Hence, mining in nature ecosystems has a negative effect on the germination performance (Hegazy 1996). These decreases in seed quality and germination in the areas adjacent to the mine reduce plant reproduction, which could contribute to decreases in vegetation cover in the longer term, as also suggested by our results. In this regard, estimating the number of young seedlings and different plant age groups in the plots by distance from the mine can be considered as an important quantitative indicator of mining effects as well. Several studies have reported different effects of dust particles on vegetation relating to the chemical properties and size of particles (Darley 1996; Grantz et al. 2003). Turner (2013) examined the impact of dust generated by iron ore mining in Australia and concluded that dust reduced plant physiological performance by over $50 \%$ and reported a radius of dust transfer up to $2000 \mathrm{~m}$. He reported the maximum dust was produced at less than 600 meters from the mine with a significant change in plant physiological parameters, supporting results of the present study. According to our findings, the reduction of the amount of dust along the leeward direction indicates the key role of the wind and its effect on the transport of particles caused by mine exploitation.

Soil microbial respiration is a soil quality indicator and the activities of microorganisms in the soil can be considered as a good indicator of overall soil metabolic activity (Bujalský et al. 2014). One of the destructive effects of mine exploitation on soil is the reduction of microbial activity. The results of this 
study confirmed that soil microbial respiration significantly decreased with decreasing distance from the mine. Dehghan (2011) studied the effect of nickel and cadmium pollution on microbial respiration and soil enzymatic activity, and found that higher soil contamination led to lower rates of microbial respiration and enzymatic activity, which is in line with the results of this research. Also, Bujalský et al. (2014) confirmed that soil microbial respiration was significantly lower in an area that had been mined for thirty years compared to an area recovered through tree planting. When the soil is contaminated, the activity of microorganisms is disturbed. As the activity of the microorganisms turns organic to mineral matter, thereby increasing the amount of nutrients available for the plants, disturbances caused by contaminants that limit microbial activity can lead to decreases in plant growth, reproduction, and highquality seed production. In sum, mine exploitation and resulting contamination can have a significant negative impact above- and belowground, affecting growth, flowering and pollination, on plant seed production and quality (Booth et al. 2003), and ultimately survival and regeneration (Waser et al. 2017).

\section{Conclusion}

This study found that the effect of the prevailing wind direction is an important factor in affecting the footprint of the mine. The results demonstrated that significant negative effects on soil and vegetation related to mining activities where more outspoken and reached further away along the leeward side of the mine. The combined effects of mine exploitation and livestock grazing in the region determined the vegetation cover, while other variables including seed mass, germination and soil respiration were suppressed closest to the mine and recovered linearly with distance to the mine for at least $600 \mathrm{~m}$. Our study suggests that bio-indicators can be used as an environmentally friendly and cost-effective method to assess the impact of mining operations. Such bio-indicators can be used to compare effects on pastures and the environment around mines and provide national and international standards on mining impacts based on the habitat type and human factors.

\section{Declarations}

\section{Acknowledgments:}

We are grateful to the Research Centre of Ardakan University for supporting this project. The authors thank Dr Fatahi A, Mr Adelzadeh A, Bagheri R for their supports during the study and field campaign. This research did not receive any specific grant from funding agencies in the public, commercial, or not-forprofit sectors.

\section{Funding}

No funding was received for conducting this study.

\section{Conflict of interest}

The authors have no conflicts of interest to declare that are relevant to the content of this article. 


\section{Author contribution}

Shahab IbrahimPour, Ali reza KhavaninZadeh and Ruhollah Thagizadeh contributed to the process for site selection and sampling method; Shahab IbrahimPour and Ali reza KhavaninZadeh conducted fieldwork and conceptualized the graphic depiction of the protocol; Shahb IbrahimPour, Alireza khavaninZadeh and Hans De Boeck analyzed and interpreted data, Alireza KhavaninZadeh wrote the initial draft and created figures; Hans De Boeck and Alvina Gul read and edited the manuscript. All authors discussed the results and contributed to the final manuscript and they read and approved it.

\section{Data availability}

The datasets used and/or analysed during the current study are available from the corresponding author on reasonable request.

\section{References}

Abbaspour M, (2011) Environment engineering, Azad university press.

Abdollahi J, Naderi H, Khavanin Zadeh A R, Farmahini M S (2015) The relation between Vegetation diversity and some of environmentally variables in Nodoushan steppe rangelands, Yazd. Journal of Iranian researches in desert and rangelands (2) 22, 251-265.

Baxter, S., 2007. World Reference Base for Soil Resources. World Soil Resources Report 103, 128.

Bech, J, Roca N, Barcelo J, et al (2012). Soil and plant contamination by lead mining in Bellmunt (Western Mediterranean Area). Journal of Geochemical Exploration 113: 94 - 99.

Box G E P, Cox D R (1964). An analysis of transformations Journal of the Royal Statistical Society, Series B 26: 211-252

Booth D T, Roos E (2003) Wyoming big sagebrush seed production from mined and unmined rangelands. Range Management. 56: 542-546.

Bujalský L, Kaneda S, Dvorščík P, Frouz J (2014) In situ soil respiration at reclaimed and unreclaimed post-mining sites: Responses to temperature and reclamation treatment, Ecological Engineering 68: 5359.

Darley, E F )1996( Studies on the effect cement-Kiln dust on vegetation. Journal of Air Pollution Control Association 16, 145-150.

Dehghan H, Bahmanyar M A, Rahimi S )2011( Effect of Ni and Cd resulted from waste sludge urban waste compost on soil respiration microbiology and enzyme activity. National conference in sustainable agriculture, Isfahan, Iran. Pp.66-77. 
Duhaime G )2004( Economic systems, Arctic Human Development Report, Akureyri, Stefansson Arctic Institute: 69-84.

Doeley D (2006) Airbourne particulates and vegetation. Review of physical interaction. Clean Air and Environmental Quality 40: 36-42.

Grantz D A, Garner J H B, Johnson D W (2003) Ecological effects of particulate matter. Environment international 29: 213-239.

Hamidian A H, Dalvand M, Zare Chahoki M, et al (2015) Investigation on concentration of $\mathrm{Cu}, \mathrm{Pb}, \mathrm{Zn}$ and Mn on aerial tissues of Artemisia sp. around Cu mine located in Darahzeresh Taft in Yazd province. Rangelnd Journal 8 (3) 219-229.

Hansen S L, Schlegel P, Legleiter L R, Lloyd K E, Spears J W, (2008) Bioavailability of copper from copper glycinate in steers fed high dietary sulfur and molybdenum Journal of Animal Science 86 (1) 173-179.

Hector M, Conesaa A, Ahmad B, et al (2009) Response of native grasses and Cicer arietinum to soil polluted with mining wastes: Implications for the management of land adjacent to mine sites. Environmental and Experimental Botany 65: 198-204.

Hui-chun YE, Yuan-fang H, Peng-fei C, et al (2016) Effects of land use change on the spatiotemporal variability of soil organic carbon in an urban-rural ecotone of Beijing, China, Journal of Integrative Agriculture 15(4): 918-928.

Humphries W R, Phillippo M, Young WB, Bremner I (1983) The influence of dietary iron and molybdenum on copper metabolism in calves British Journal of Nutrition 49 (1) 77-86.

Hegazy A (1996) Effects of cement-kiln dust pollution on the vegetation and seed-bank species diversity in the eastern desert of Egypt. Environmental Conservation 23(3) 249-258.

doi:10.1017/S0376892900038868.

ISO 16072 (2002) Soil quality - laboratory methods for determination of microbial soil respiration. International Organization for Standardization. Geneva, Switzerland.

Kumar N (2015) Effect of different mining dust on the vegetation of district balaghat, M.P - A Critical Review International Journal of Science and Research 4 (8) 603-307.

Lambers, H, Chapin F S, Pons T L (2008) Photosynthesis. In Plant physiological ecology (pp. 11-99). Springer, New York, NY.

Litzow E (2015) Sheep diseases. The farmers guide. Biosecurity SA Pirsa. 2 Ed. Pp.84.

Liu L, Liu J, Zhang Z, (2014) Environmental justice and sustainability impact assessment: In search of solutions to ethnic conflicts caused by coal mining in Inner Mongolia China. Sustainability 6 (12) 8756- 
8774.

Lohr V I, Pearson-Mims C H, (1996) Particulate matter accumulation on horizontal surfaces in interiors: influence of foliage plants. Atmospheric environment, 30 (14) 2565-2568.

Moghadam M.R, 2009. Range management. Tehran University.

Reeves, R D, Baker A J M (2000) Metal-accumulating plants In: Raskin I, Ensley BD (eds) Phytoremediation of toxic metals: using plants to clean up the environment. Wiley, New York, 193-229.

Santos J, Castro-Rodriguez A, Huezo-Casillas J, Torres-Bustillos L (2012) Arsenic and heavy metals in native plants at tailings impoundments in Queretaro, Mexico. Physics and Chemistry of the Earth, 37 39: $10-17$.

Sharifi M R, Gibson A C, Rundel P W, (1997) Surface dust impacts on gas exchange in Mojera desert Shrubs J. App. Eco. 94 (4): 834-846.

Suttle N F, Peter D W, (1985) Rumen sulfide metabolism as a major determinant of the availability of copper to ruminants, in Proceedings of the 5th International Symposium on Trace Elements in Man and Animals, Mills C F, et al Eds, pp. 367-370, Royal Slough Commonwealth Agricultural Bureau, Farnham, UK.

Stadtman E R, Oliver C N (1991) Metal-catalyzed oxidation of proteins J. Bio. Chem. 266: 2005-2008.

Taghizadeh-Mehrjardi R,Schmidt K, Eftekhari K, et al. 2020, Synthetic resamplingstrategies and machine learning for digital soilmapping in Iran. Eur J Soil Sci. 71:352-368.

Tuner G F (2013) Vulnerability of vegetation to mining dust at the Jack hill, Western Australia. Dissertation, university of western Australia.

Waser N M, Price M V, Casco G, Diaz M, Morales L, Solverson J (2017) Effect of road dust on the pollination and reproduction of wild flowers. Plant Sci. 178 (2):85-93.

Zonneveld I S (1989) The land unit-a fundamental concept in landscape ecology, and its applications. Landscape ecology. 3(2): 67-86.

\section{Figures}




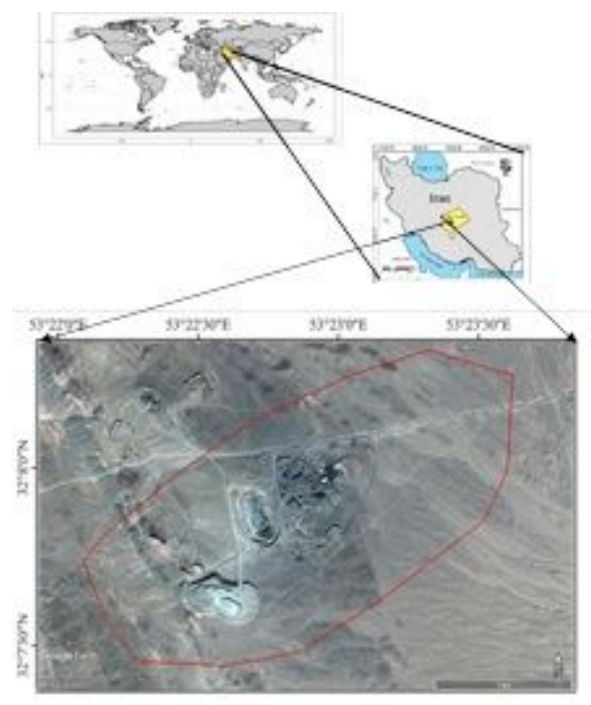

\section{Figure 1}

Location of the mine site in the study area in Iran and the world. Note: The designations employed and the presentation of the material on this map do not imply the expression of any opinion whatsoever on the part of Research Square concerning the legal status of any country, territory, city or area or of its authorities, or concerning the delimitation of its frontiers or boundaries. This map has been provided by the authors.

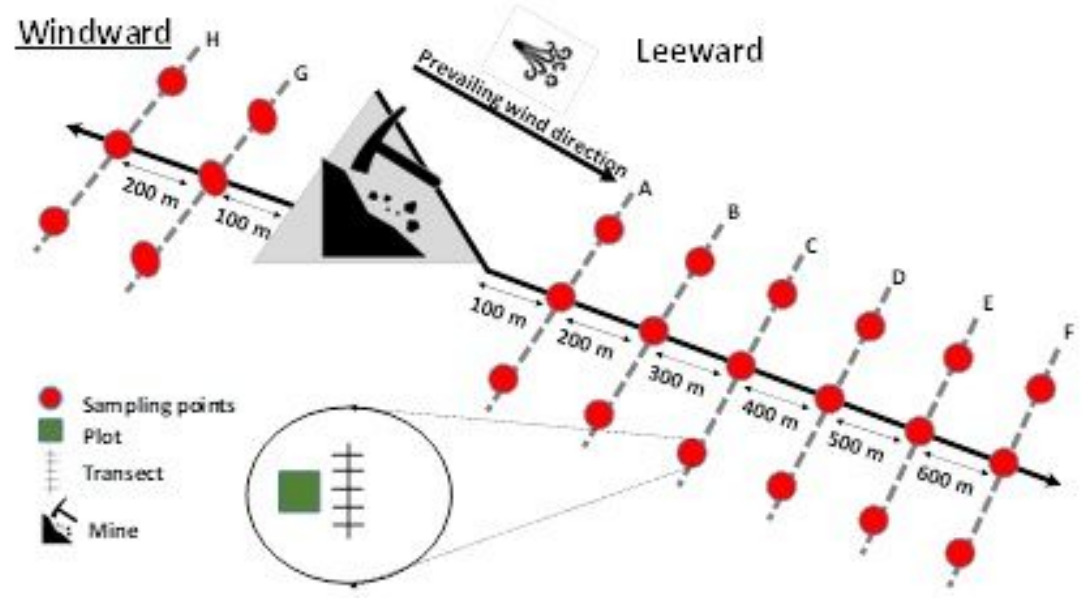

Figure 2

Sampling locations in relation to distance from the iron ore mine, along the prevailing wind direction. 


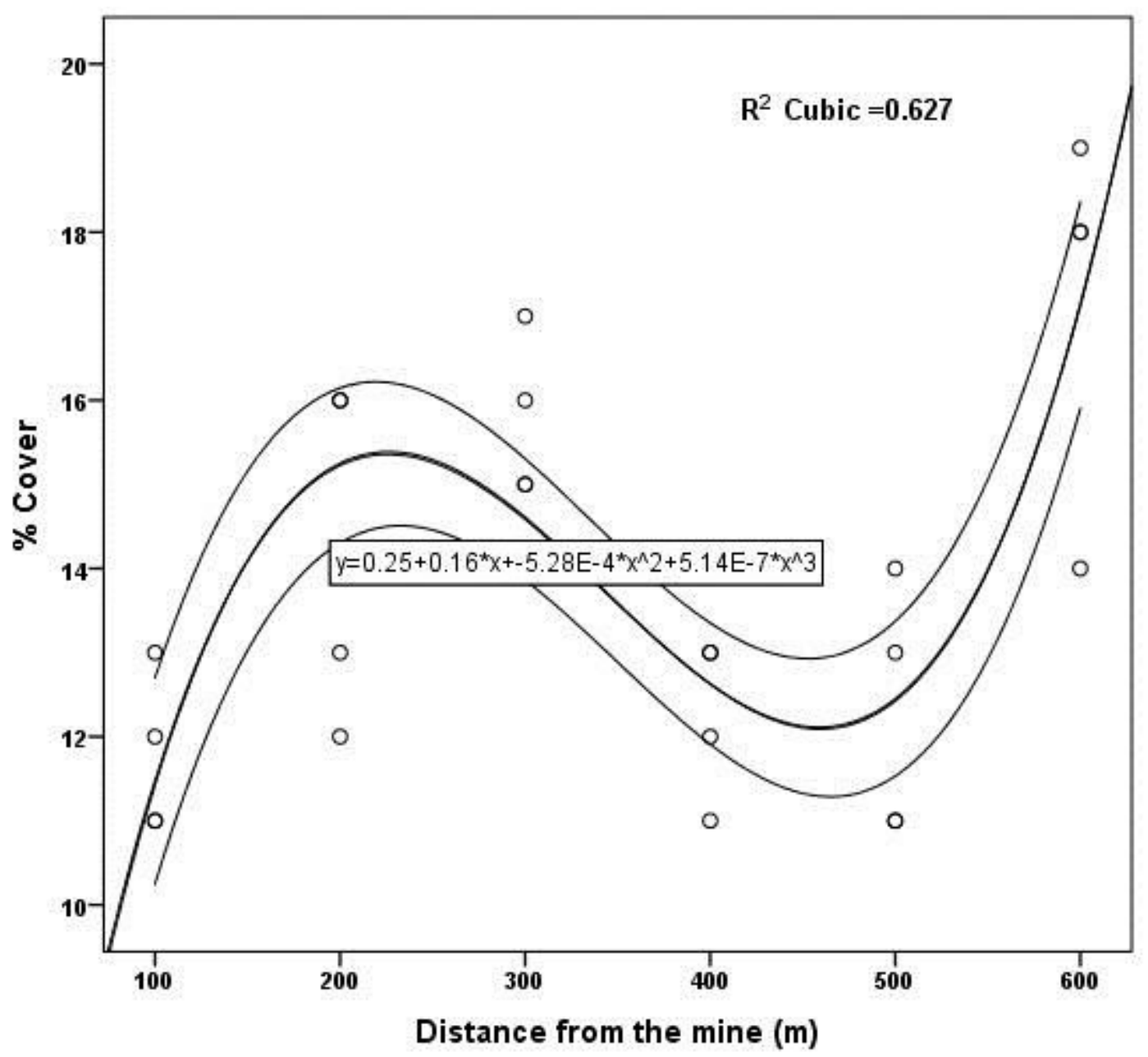

Figure 3

Vegetation cover at different distances from the iron ore mine in leeward direction, with a non-linear regression and confidence intervals indicated. 


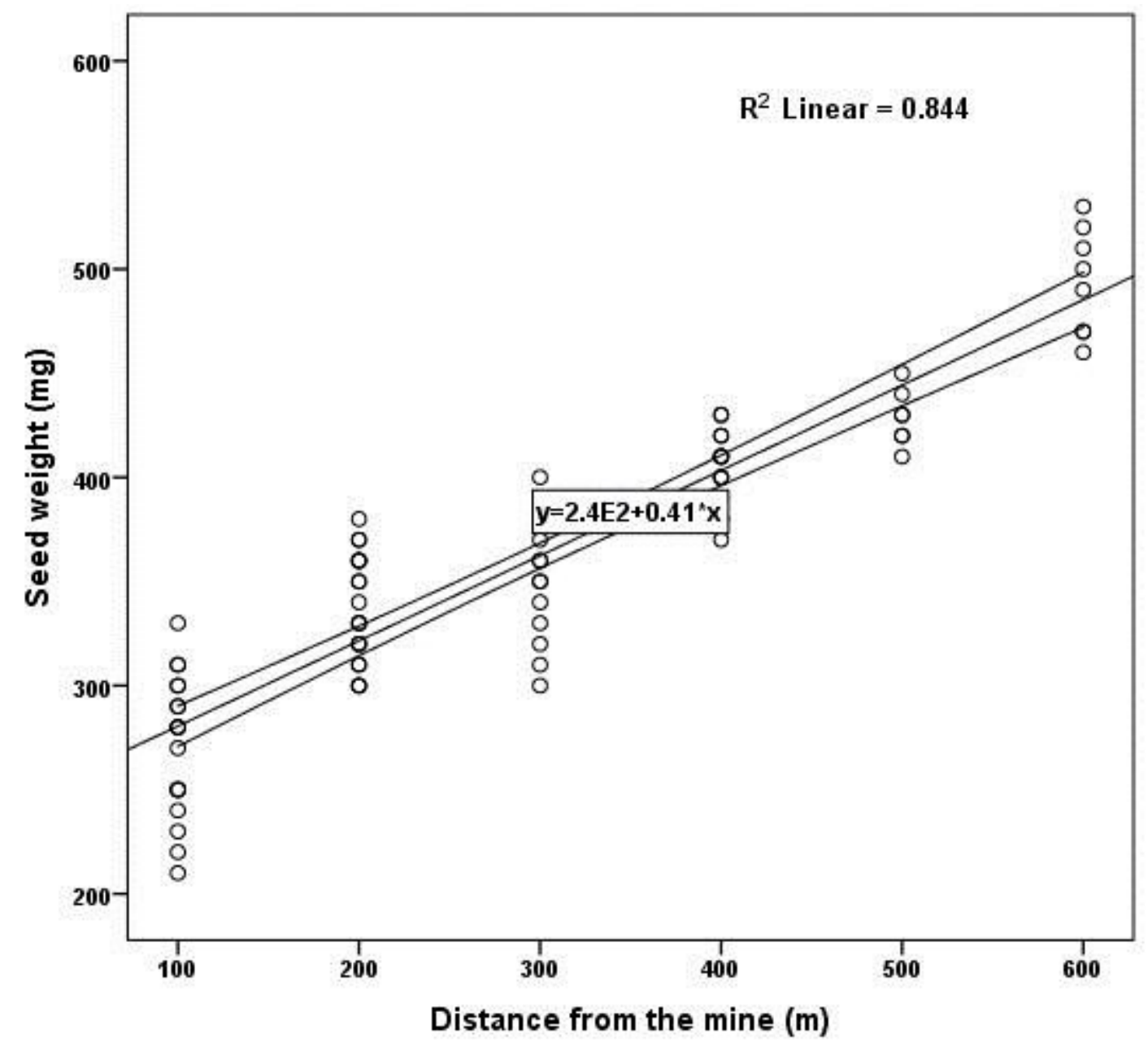

\section{Figure 4}

Weight of 1000 seed at different distances from the iron ore mine in leeward direction, with a linear regression and confidence intervals indicated 


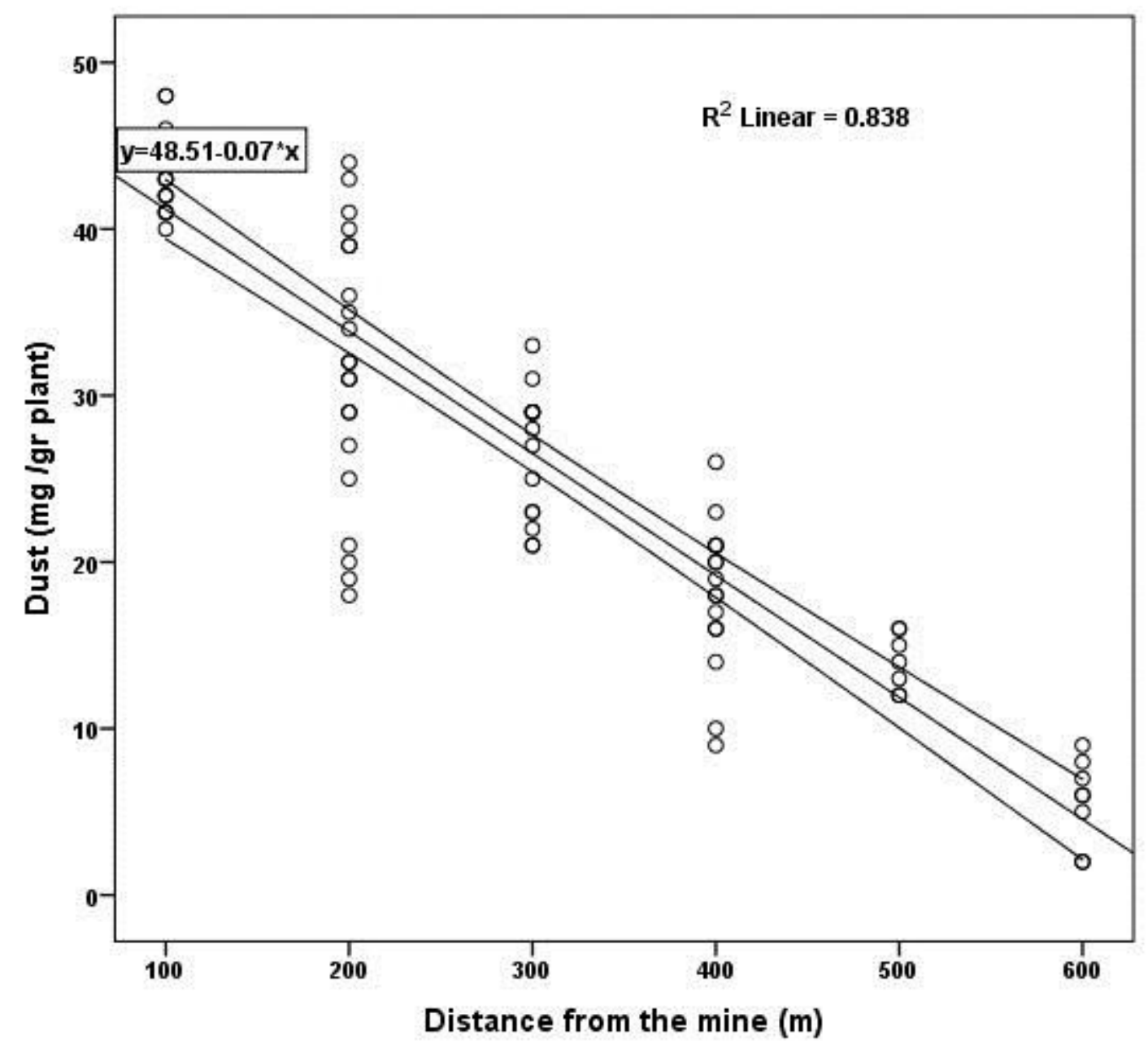

Figure 5

Dust deposited on the plants at different distances from the iron ore mine in leeward direction, with a linear regression and confidence intervals indicated 


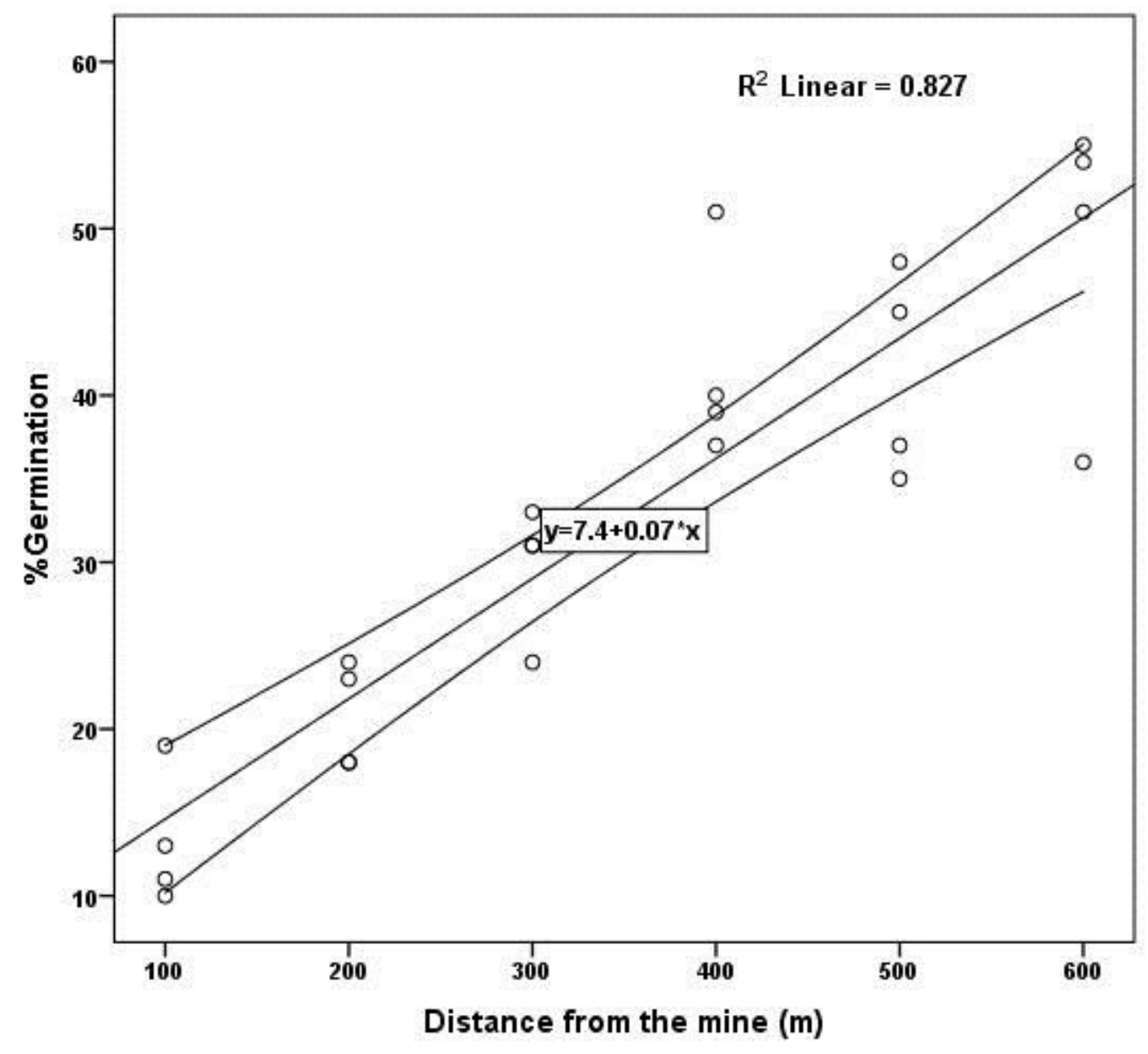

Figure 6

Rate of seed germination at different distances from the iron ore mine in leeward direction, with a linear regression and confidence intervals indicated. 


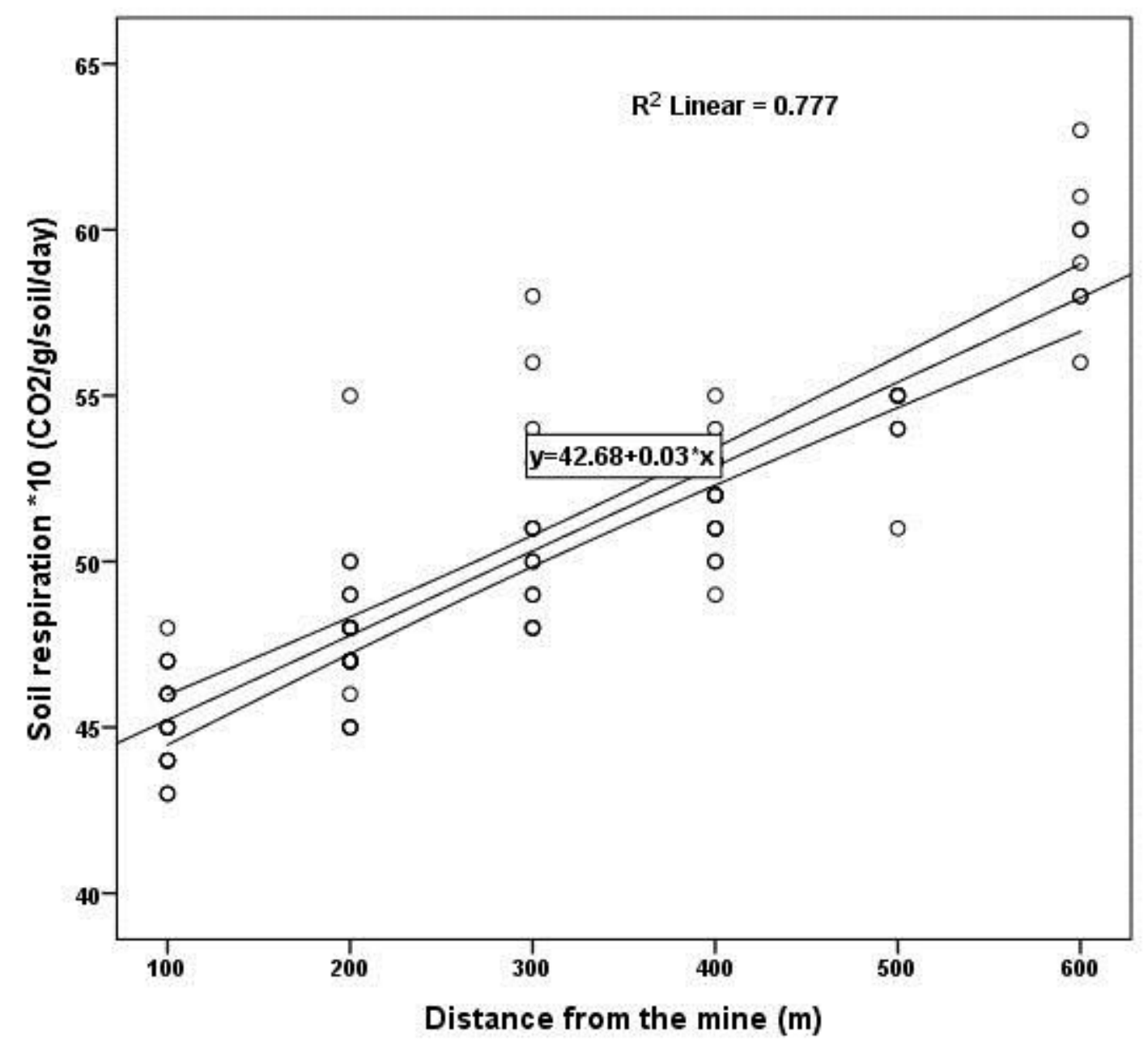

\section{Figure 7}

Microbial soil respiration at different distances from the iron ore mine in leeward direction, with a linear regression and confidence intervals indicated. 